\title{
Glandular Cell Neoplasm
}

National Cancer Institute

\section{Source}

National Cancer Institute. Glandular Cell Neoplasm. NCI Thesaurus. Code C7132.

A benign or malignant, primary or metastatic epithelial neoplasm affecting the glandular cells. 